\title{
IMMUNIZATION OF HUMAN SUBJECTS WITH THE SPECIFIC CARBOHYDRATES OF TYPE III AND THE RELATED TYPE VIII PNEUMOCOCCUS ${ }^{1}$
}

\author{
By MAXWELL FINLAND AND JAMES M. RUEGSEGGER \\ (From the Thorndike Memorial Laboratory, Second and Fourth Medical Services (Harvard), \\ Boston City Hospital and the Department of Medicine, Harvard Medical School, Boston)
}

(Received for publication June 29, 1935)

Sugg and Harris and their respective coworkers were the first to study extensively the immunologic properties of a strain of pneumococcus closely related to, but not identical with, typical strains of Type III pneumococci $(1,2)$. The "Thomas" strain of these workers now can be classified definitely as a Type VIII pneumococcus, according to the classification of Cooper et al. (3). Both the Thomas strain and the Type VIII strains were shown, by these respective investigators, to produce in certain animal species antibodies of high titer against typical strains of Type III pneumococci. The titers were sometimes higher than the notoriously low homologous antibody titers obtainable by the injection of typical Type III strains. The reciprocal serological relationships between typical Type III strains and the related Type VIII strains were demonstrated with regard to passive protection in mice, agglutination, and precipitation. Antibody relationships similar to those described in the sera of lower animals were shown, by Finland and Winkler (4), to occur also in the sera of certain human subjects during convalescence from pneumonia due to these types. With regard to "natural antibodies," as measured by the pneumococcidal power of the whole defibrinated blood or the protection afforded mice by the serum of normal human subjects, Finland and Sutliff found no such reciprocal relationship (5).

The specific carbohydrate from Pneumococcus Type VIII was recently isolated and its properties described by Brown (6). She found marked cross-precipitation between this carbohydrate and that of the Type III pneumococcus. In view of this finding and because of the poor antibody response of human subjects to injections of the

1 This investigation was aided, in part, by a grant given in honor of Francis Weld Peabody by the Ella Sachs Plotz Foundation.
Type III polysaccharide (7), it seemed of interest to study the effect of injections of the Type VIII carbohydrate. This paper deals with the antibody responses to such injections and a comparison of them with the results of similar injections of different preparations of the specific Type III polysaccharide. Variations in the antibody response due to differences in dosage and in the route of injection are dealt with in a separate communication (8).

\section{EXPERIMENTAL}

\section{Subjects, materials and methods}

The Type VIII carbohydrate was obtained from Dr. Rachel Brown and was, in most respects, similar to the preparation which she described (6). Her analysis showed it to contain 0.72 per cent nitrogen, 0.11 per cent phosphorus, 39.69 per cent carbon, 6.15 per cent hydrogen, and 6.37 per cent ash. It yielded 69.5 per cent reducing sugars after acid hydrolysis. It precipitated the homologous type antiserum in a dilution of $1: 4,000,000$ and Type III antiserum in a dilution of $1: 2,000,000$. In the presence of the homologous immune rabbit serum, it fixed complement. Mice injected with amounts varying from 0.1 to $0.000001 \mathrm{mgm}$. were not protected against subsequent injections of culture. Most of the preparations of the Type III polysaccharide have been used in previous immunization studies $(7,9)$.

The subjects were adult hospital patients who were free from recent febrile diseases. Each individual received a single subcutaneous injection of $1.0 \mathrm{mgm}$. of one carbohydrate preparation over the deltoid insertion. This dosage and route were found to yield the best results with the Type VIII material (8). No local or general reactions occurred following any of the injections. Blood for the study of antibodies was drawn before and at intervals after injections. Phagocytosis was studied by a method similar to that used by Ward and Enders (10). Agglutinins were determined by the technique employed by Tillett and Francis (11), and the mouse protective titer was obtained by the method of Dochez (12). Organisms of maximum virulence were used throughout the experiments. 


\section{RESULTS}

Homologous antibody response elicited by the Type VIII carbohydrate

The results of tests for the development of agglutinins, mouse protective antibodies and opsonins for the homologous type of pneumococcus in the 12 subjects who received a single subcutaneous injection of $1.0 \mathrm{mgm}$. of the Type VIII carbohydrate are shown in Table I. They indicate that an appreciable titer of the antibodies was stimulated in each instance. The response was demonstrated with greater regularity in these subjects than in patients recovering from pneumonia due to the same type of organism. The maximum titer of antibodies was reached in about 2 weeks and was maintained, approximately at this level, throughout the period of observation in 4 subjects whose sera were studied 6 to 8 weeks, and in 2 subjects almost 5 months after the injection. In 1 subject (J. N.) a drop in titer occurred between the 49th and the 121st day, no blood having been obtained in this interval.

\section{Homologous antibody response to injection of Type III polysaccharide}

In previous attempts to immunize human subjects with Type III pneumococcus polysaccharide, single or multiple doses of 0.01 to $0.05 \mathrm{mgm}$. were given intracutaneously (7). In view of the more constant and higher grade response obtained by subcutaneous injections of $1.0 \mathrm{mgm}$. of the Type VIII carbohydrate, a study was made of the response of human subjects to Type III materials given in this manner. A single injection of 1.0 $\mathrm{mgm}$. of one of 6 preparations of the Type III carbohydrate was given subcutaneously to each of 41 subjects, and the antibody response in them was studied in a manner similar to that employed for the Type VIII cases.

The results are summarized in Table II. In general, inconstant and low-grade responses were secured. They were similar to those previously obtained with the smaller doses given intracutaneously (7) and somewhat less marked than those observed to develop in patients recovering from pneumonia due to the same type of pneumococcus (4).

TABLE I

Antibody response to subcutaneous injection of $1.0 \mathrm{mgm}$. of Pneumococcus Type VIII soluble specific substance

\begin{tabular}{|c|c|c|c|c|c|}
\hline \multirow[b]{2}{*}{$\begin{array}{l}\text { Subject } \\
\text { Ser and } \\
\text { age }\end{array}$} & \multirow[b]{2}{*}{$\begin{array}{l}\text { Days } \\
\text { after } \\
\text { injec- } \\
\text { tion }\end{array}$} & \multicolumn{3}{|c|}{ Titer of Type VIII antibodies } & \multirow[b]{2}{*}{ Type III antibodies } \\
\hline & & $\begin{array}{l}\text { Agglu- } \\
\text { tinins } \\
\text { (serum } \\
\text { dilution) }\end{array}$ & $\begin{array}{c}\text { Mouse } \\
\text { protection } \\
\text { (Fatal } \\
\text { doses per } \\
0.2 \text { cc.) }\end{array}$ & $\begin{array}{c}\text { Phagocytosis } \\
\text { (Average } \\
\text { number } \\
\text { diplococei } \\
\text { per } \\
\text { polymorpho- } \\
\text { nuclesr } \\
\text { leukoeyto) }\end{array}$ & \\
\hline M.S. $_{22}$ & $\begin{array}{r}0 \\
3 \\
7 \\
14 \\
24 \\
56\end{array}$ & $\begin{array}{c}0 \\
0 \\
0 \\
1: 4 \\
1: 4 \\
1: 8\end{array}$ & $\begin{array}{r}\overline{10} \\
100 \\
1,000,000 \\
1,000,000 \\
10,000,000\end{array}$ & $\begin{array}{r}1.5 \\
0.9 \\
4.0 \\
9.4 \\
16.8 \\
12.2\end{array}$ & No change \\
\hline $\mathrm{M}^{\text {F.C. }}$ & $\begin{array}{r}0 \\
3 \\
7 \\
14 \\
31 \\
50 \\
146\end{array}$ & $\begin{array}{c}0 \\
0 \\
0 \\
1: 2 \\
1: 4 \\
1: 4 \\
0\end{array}$ & $\begin{array}{r}0 \\
10 \\
1,000 \\
1,000,000 \\
100,000 \\
100,000 \\
100,000\end{array}$ & $\begin{array}{l}2.0 \\
2.9 \\
6.2 \\
18.8 \\
11.6 \\
13.1\end{array}$ & No change \\
\hline F.S. & $\begin{array}{r}0 \\
3 \\
7 \\
14 \\
28 \\
47 \\
143\end{array}$ & $\begin{array}{c}0 \\
0 \\
1: 2 \\
1: 16 \\
1: 8 \\
1: 8 \\
1: 8\end{array}$ & $\begin{array}{r}\frac{0}{1,000} \\
1,000,000 \\
1,000,000 \\
1,000,000 \\
100,000\end{array}$ & \begin{tabular}{r|}
0.5 \\
1.4 \\
21.1 \\
11.5 \\
21.8 \\
11.6 \\
31.8
\end{tabular} & $\begin{array}{l}\text { Protection: before }=0 \\
14 \text { th day } 1000 \text { fatal doses } \\
28 \text { th day } 0 \\
\text { No other change }\end{array}$ \\
\hline$\underset{\mathbf{F}}{\mathbf{M} . \mathbf{M e G}}$ & $\begin{array}{r}0 \\
3 \\
7 \\
14 \\
53\end{array}$ & $\begin{array}{c}0 \\
0 \\
1: 2 \\
1: 8 \\
1: 16\end{array}$ & $\begin{array}{r}100 \\
10 \\
10,000 \\
10,000,000 \\
1,000,000\end{array}$ & $\begin{array}{r}2.8 \\
1.4 \\
21.4 \\
10.4 \\
10.2\end{array}$ & $\begin{array}{l}\text { Phagocytosis increased } \\
\text { from } 0.6 \text { to } 2.8\end{array}$ \\
\hline $\begin{array}{l}\text { W.:H.M. } \\
\mathbf{M} 68\end{array}$ & $\begin{array}{r}0 \\
8 \\
15 \\
18 \\
25 \\
44\end{array}$ & $\begin{array}{c}0 \\
0 \\
1: 2 \\
1: 4 \\
1: 4 \\
1: 4\end{array}$ & $\begin{array}{r}0 \\
10,000 \\
100,000 \\
100,000 \\
1,000,000\end{array}$ & $\begin{array}{r}0.7 \\
3.3 \\
11.8 \\
9.8 \\
16.4 \\
16.0\end{array}$ & $\begin{array}{l}\text { Protection: before = } \\
10 \text { fatal doses } \\
25 \text { th and } 44 \text { th day }= \\
100 \text { fatal doses }\end{array}$ \\
\hline $\begin{array}{l}\text { J.P.C. } \\
\mathbf{M}\end{array}$ & $\begin{array}{r}0 \\
8 \\
15 \\
51\end{array}$ & $\begin{array}{l}0 \\
1: 2 \\
1: 16 \\
1: 4\end{array}$ & $\begin{array}{r}10 \\
1,000 \\
10,000 \\
100,000\end{array}$ & $\begin{array}{r}1.1 \\
16.2 \\
11.2 \\
-\end{array}$ & No change \\
\hline $\mathrm{F}^{\text {8.B. }}$ & $\begin{array}{r}0 \\
7 \\
14 \\
19 \\
28\end{array}$ & $\begin{array}{c}0 \\
0 \\
1: 2 \\
1: 2 \\
1: 8\end{array}$ & $\begin{array}{r}0 \\
0 \\
0 \\
100 \\
100\end{array}$ & $\begin{array}{r}5.8 \\
7.6 \\
26.8 \\
38.2 \\
30.0\end{array}$ & No change \\
\hline$\underset{\mathbf{F}}{\mathbf{S . V} . \mathbf{C}}$ & $\begin{array}{r}0 \\
7 \\
10 \\
14\end{array}$ & $\begin{array}{c}0 \\
0 \\
1: 4 \\
1: 4\end{array}$ & $\begin{array}{r}10 \\
\frac{100}{1,000,000} \\
\end{array}$ & $\begin{array}{r}6.0 \\
4.0 \\
14.0 \\
19.5\end{array}$ & \\
\hline$\dot{\mathbf{M}}^{\mathbf{N}} \mathbf{\mathrm { N }}$ & $\begin{array}{r}0 \\
49 \\
121 \\
131\end{array}$ & $\begin{array}{c}0 \\
1: 8 \\
1: 2 \\
1: 2\end{array}$ & $\begin{array}{r}0 \\
100,000 \\
10 \\
100\end{array}$ & $\begin{array}{l}2.5 \\
7.7 \\
2.8 \\
1.3\end{array}$ & No change \\
\hline$\underset{\mathbf{M}}{\mathbf{E} . \mathbf{J} . \mathbf{B}} \mathbf{7 5}$ & $\begin{array}{r}0 \\
7 \\
14\end{array}$ & $\begin{array}{l}1: 2 \\
1: 2 \\
1: 4\end{array}$ & $\begin{array}{r}10 \\
100 \\
100,000\end{array}$ & $\begin{array}{r}5.2 \\
4.0 \\
19.9\end{array}$ & \\
\hline$\underset{\mathbf{F}}{\mathbf{M . K}}$ & $\begin{array}{r}\mathbf{0} \\
\mathbf{3} \\
\mathbf{7} \\
\mathbf{1 1}\end{array}$ & $\begin{array}{r}\mathbf{0} \\
\mathbf{0} \\
\mathbf{0} \\
\mathbf{3 2}\end{array}$ & $\begin{array}{r}0 \\
10 \\
10,000 \\
1,000,000\end{array}$ & $\begin{array}{r}2.0 \\
1.6 \\
19.6 \\
13.0\end{array}$ & No change \\
\hline$\underset{\mathbf{M}}{\mathbf{K} . R .}$ & $\begin{array}{r}0 \\
8 \\
23\end{array}$ & $\begin{array}{c}0 \\
1: 2 \\
1: 4\end{array}$ & $\begin{array}{r}0 \\
0 \\
1,000\end{array}$ & $\begin{array}{r}1.3 \\
16.0 \\
\end{array}$ & No change \\
\hline
\end{tabular}


TABLE II

Antibodies against Type III and Type VIII pneumococci resulting from a single subcutaneous injection of 1.0 mgm. of the polysaccharides of these organisms

\begin{tabular}{|c|c|c|c|c|c|c|c|c|c|c|c|c|c|c|}
\hline \multirow{2}{*}{\multicolumn{2}{|c|}{ Polysaccharide }} & \multirow{3}{*}{$\begin{array}{c}\text { Num- } \\
\text { ber } \\
\text { of } \\
\text { sub- } \\
\text { jects }\end{array}$} & \multicolumn{12}{|c|}{ Number showing increases in titer of antibodies } \\
\hline & & & \multicolumn{4}{|c|}{ Agglutinins* } & \multicolumn{4}{|c|}{ Mouse protection $\uparrow$} & \multicolumn{4}{|c|}{ Phagocytoriał } \\
\hline Type & Lot & & o & 2 & 4 & $8+$ & 0 & 10 & 100 & $1000+$ & $\mid \begin{array}{c}0 \\
\text { to } \\
1\end{array}$ & $\begin{array}{l}2 \\
\text { to } \\
5\end{array}$ & $\begin{array}{l}6 \\
\text { to } \\
10\end{array}$ & $11+$ \\
\hline \multicolumn{15}{|c|}{ Type VIII antibodies } \\
\hline VIII & WS3 & 12 & o & 1 & 4 & 7 & $\mathbf{0}$ & $\mathbf{0}$ & 1 & 11 & 0 & 1 & 0 & 11 \\
\hline $\begin{array}{l}\text { III } \\
\text { III } \\
\text { III } \\
\text { III } \\
\text { III } \\
\text { III }\end{array}$ & $\begin{array}{l}\text { WSAc } \\
\text { WS3 } \\
\text { WC } \\
\text { RS } \\
\text { FA } \\
\text { FB }\end{array}$ & $\begin{array}{l}8 \\
6 \\
6 \\
5 \\
8 \\
7\end{array}$ & $\begin{array}{l}7 \\
6 \\
5 \\
2 \\
4 \\
5\end{array}$ & $\begin{array}{l}1 \\
0 \\
1 \\
1 \\
3 \\
0\end{array}$ & $\begin{array}{l}0 \\
0 \\
0 \\
1 \\
1 \\
2\end{array}$ & $\begin{array}{l}0 \\
0 \\
0 \\
18 \\
0 \\
0\end{array}$ & $\begin{array}{l}5 \\
4 \\
3 \\
3 \\
6 \\
1\end{array}$ & $\begin{array}{l}2 \\
2 \\
3 \\
1 \\
1 \\
3\end{array}$ & $\begin{array}{l}1 \\
0 \\
0 \\
0 \\
0 \\
0\end{array}$ & $\begin{array}{l}0 \\
0 \\
0 \\
111 \\
1 \\
0\end{array}$ & $\begin{array}{l}5 \\
4 \\
4 \\
2 \\
4 \\
3\end{array}$ & $\begin{array}{l}3 \\
1 \\
2 \\
2 \\
2 \\
1\end{array}$ & $\begin{array}{l}0 \\
0 \\
0 \\
0 \\
2\end{array}$ & $\begin{array}{l}0 \\
1 \\
0 \\
1 \\
0 \\
2\end{array}$ \\
\hline \multicolumn{2}{|c|}{ All Type III lots } & 40 & 29 & 6 & 4 & 1 & 25 & 12 & 1 & 2 & 22 & 11 & 3 & 4 \\
\hline \multicolumn{15}{|c|}{ Type III antibodies } \\
\hline VIII & WS3 & 12 & 12 & 0 & 0 & 0 & 10 & 1 & 0 & 1 & 11 & 1 & 0 & $\mathbf{0}$ \\
\hline $\begin{array}{l}\text { III } \\
\text { III } \\
\text { III } \\
\text { III } \\
\text { III }\end{array}$ & $\begin{array}{l}\text { WS40 } \\
\text { W83 } \\
\text { WC } \\
\text { RS } \\
\text { FA } \\
\text { FB }\end{array}$ & $\begin{array}{l}9 \\
6 \\
6 \\
5 \\
8 \\
7\end{array}$ & $\begin{array}{l}6 \\
5 \\
5 \\
3 \\
6 \\
3\end{array}$ & $\begin{array}{l}1 \\
0 \\
0 \\
1 \\
0 \\
0\end{array}$ & $\begin{array}{l}1 \\
0 \\
1 \\
0 \\
1 \\
1\end{array}$ & $\begin{array}{l}11 \\
1 * \\
0 \\
1 * * \\
1 \\
3+t\end{array}$ & $\begin{array}{l}3 \\
3 \\
2 \\
1 \\
2 \\
2 \\
2\end{array}$ & $\begin{array}{l}1 \\
2 \\
0 \\
1 \\
4 \\
1 \\
\end{array}$ & $\begin{array}{l}2 \\
0 \\
2 \\
2 \\
0 \\
1\end{array}$ & $\begin{array}{l}39 \\
1 \text { 1f } \\
2 f \\
111 \\
2 \\
3 \$ 8\end{array}$ & \begin{tabular}{|l|}
3 \\
5 \\
4 \\
3 \\
3 \\
6 \\
3
\end{tabular} & $\begin{array}{l}1 \\
1 \\
1 \\
1 \\
1 \\
1\end{array}$ & $\begin{array}{l}3 \\
0 \\
1 \\
0 \\
1 \\
1\end{array}$ & $\begin{array}{l}21 \\
0 \\
0 \\
1 \\
0 \\
2\end{array}$ \\
\hline \multicolumn{2}{|c|}{ All Type III lots } & 41 & 28 & 2 & 4 & 7 & 13 & 9 & 7 & 12 & 24 & 6 & 6 & 5 \\
\hline
\end{tabular}

$* 0,2$, etc. $=$ no increase, twofold increase, etc., in highest dilution showing agglutination.

$\dagger 0,10$, etc. $=0$, tenfold, etc., increase in fatal doses of protection.

$\ddagger 0$ to 1,2 to 5 , etc., = increase in average number of diplococci phagocyted per polymorphonuclear leukocyte.

$\S 1: 32$.

|| 1,000,000 fatal doses.

II Serum of same subject increased 16-fold in protection and an average of 22 diplococci per polymorphonuclear leukocyte.

** 16-fold increase.

t† 1 increased 16-fold, another 32-fold.

$\# 10,000$-fold increase.

$\$ \S 2$ increased 10,000-fold.

Antibodies for the heterologous but related type following an injection of the Type III or the

Type VIII pneumococcus carbohydrate

The sera of all of the subjects receiving an injection of either the Type III or the Type VIII carbohydrate were tested for antibodies against both types of organism. The results are summarized in Table II. Only 1 of the subjects (F. S.) injected with the Type VIII material showed an appreciable development of antibodies for the Type III organism. Other subjects, as described in the paper that follows (8), were encountered whose sera showed Type III antibodies in low titer following the injection of the Type VIII material in different amounts or by routes other than the subcutaneous one.

The Type III preparations used were all similar in their antigenicity as regards both the homologous and the related type of antibody. Antibodies of significant titer against Type VIII following injections of Type III polysaccharide were infrequent. Low titers of such antibodies, however, were demonstrated in almost half of the subjects who received Type III materials.

The findings described indicate that the common antigen of the Types III and VIII pneumococci is retained, at least in part, in these highly purified fractions. Less of it is retained in the Type VIII than in the Type III materials. In either case, however, the antibody response to the related type was less frequent than that following injections of the intact organisms in lower animals $(1,2,3)$, or than that found in patients recovering from pneumonia due to these types (4).

\section{Development of antibodies against heterologous and unrelated pneumococcus types}

The development of antibodies for heterologous types of pneumococci has been reported to follow injections of Type I and II pneumococcus fractions in lower animals (13) and in human beings (14). In the present investigation, in addition to tests for antibodies against the homologous and the related types of organisms (Type III and Type VIII), similar tests were carried out on the sera of each subject with either Type I or Type II pneumococci. None of the subjects who received Type VIII injections showed any increase in antibodies against either of these types by any of the tests employed. Among those receiving the Type III polysaccharide, 3 subjects developed or increased their titer of antibodies against an heterologous type as shown by mouse protection and phagocytic tests. Agglutinins did not appear in the serum. Only 1 of the 3 subjects developed Type VIII antibodies.

One subject received $1.0 \mathrm{mgm}$. of Type III preparation FA and developed antibodies as follows: Type III ag- 
glutinins appeared in dilution of $1: 8$, mouse protection against 10,000 fatal doses and an increase in phagocytic titer from 0.8 to 10.3 diplococci per polymorphonuclear leukocyte; Type VIII agglutinins increased from 1:2 to $1: 8$, protection from 10 to 10,000 fatal doses and the phagocytic titer from 0.5 to 7.0 ; Type I protection increased from 1000 to 100,000 fatal doses and the phagocytic titer from 13.4 to 23.5 . In a second subject receiving the same material no Type III or VIII antibodies appeared, but the protective titer of the serum against Type I increased from 10 to 10,000 fatal doses and the phagocytic titer for this type increased from 1.9 to 22.4 diplococci per polymorphonuclear leukocyte. A third subject who received preparation RS developed protective antibodies against 100 fatal doses of Type III and against 1000 fatal doses of Type II pneumococci. The phagocytic titer increased only against Type II pneumococci, the titer being 1.7 before and 16.7 after the injection.

These findings indicate that a species antigen may be present in the pneumococcus but that it is largely lost in the process of preparation of the carbohydrate fractions (cf. 15). In the case of some of the Type III preparations, the data suggest that sufficient of this species antigen was retained to give rise to Type I or Type II antibodies in measurable amounts in an occasional subject.

\section{SUM MARY}

1. High titers of antibodies against the homologous type were demonstrated regularly in human subjects following the subcutaneous injection of $1.0 \mathrm{mgm}$. of a highly purified, type-specific carbohydrate of Pneumococcus Type VIII.

2. Various preparations of the Type III pneumococcus polysaccharide, given in the same manner, produced antibodies for the homologous type with less regularity and in lower titers.

3. Occasional subjects injected with Type III or with the related Type VIII pneumococcus carbohydrate developed antibodies against pneumococci of the heterologous but related type. Such cross-immunity, however, was less frequent and of a lower grade than that encountered either in animals immunized with the whole organism or in human patients recovering from pneumonia due to these types of pneumococcus.

The authors express their gratitude to Dr. Rachel Brown and Dr. Augustus B. Wadsworth for providing most of the carbohydrate preparation and for their kindly interest.

\section{BIBLIOGRAPHY}

1. Sugg, J. Y., Gaspari, E. L., Fleming, W. L., and Neill, J. M., Studies on immunological relationships among the pneumococci. I. A virulent strain of pneumococcus which is immunologically related to, but not identical with, typical strains of Type III pneumococci. J. Exper. Med., 1928, 47, 917.

2. Harris, A. L., Sugg, J. Y., and Neill, J. M., Studies on immunological relationships among the pneumococci. II. A comparison of the antibody responses of mice and of rabbits to immunization with typical Type III pneumococci and to immunization with a related strain. J. Exper. Med., 1928, 47, 933.

3. Cooper, G., Edwards, M., and Rosenstein, C., The separation of types among the pneumococci hitherto called Group IV and the development of therapeutic antiserums for these types. J. Exper. Med., 1929, 49, 461.

4. Finland, M., and Winkler, A. W., Antibody response to infections with Type III and the related Type VIII pneumococcus. J. Clin. Invest., 1934, 13, 79.

5. Finland, M., and Sutliff, W. D., Immunity reactions of human subjects to strains of pneumococci other than Types I, II and III. J. Exper. Med., 1933, 57, 95.

6. Brown, R., The specific carbohydrate from Pneumococcus Type VIII. Proc. Soc. Exper. Biol. and Med., 1935, 32, 859.

7. Finland, M., and Dowling, H. F., Cutaneous reactions and antibody response to intracutaneous injections of pneumococcus polysaccharides. J. Immunol. (In press).

8. Ruegsegger, J. M., and Finland, M., The influence of dosage and route of injection on the antibody response of human subjects to the specific carbohydrate of the Type VIII pneumococcus. J. Clin. Invest., 1935, 14, 833.

9. Finland, M., and Sutliff, W. D., Specific antibody response of human subjects to intracutaneous injection of pneumococcus products. J. Exper. Med., 1932, 55, 853.

10. Ward, H. K., and Enders, J. F., An analysis of the opsonic and tropic action of normal and immune sera based on experiments with the pneumococcus. J. Exper. Med., 1933, 57, 527.

11. Tillett, W. S., and Francis, T., Jr., Cutaneous reactions to the polysaccharides and proteins of pneumococcus in lobar pneumonia. J. Exper. Med., 1929, $50,687$.

12. Dochez, A. R., The presence of protective substances in human serum during lobar pneumonia. $J$. Exper. Med., 1912, 16, 665.

13. Day, H. B., Species immunity to pneumococcus. J. Path. and Bact., 1933, 36, 77.

14. Felton, L. D., Sutliff, W. D., and Steele, B. F., Antigenic characteristics in man of certain products of the pneumococcus. J. Infect. Dis., 1935, 56, 101.

15. Day, H. B., The preparation of pneumococcal species antigen. J. Path. and Bact., 1934, 38, 171. 